\title{
The Mosque Colo as Alternative Tourism Destination in Kudus
}

\author{
$1^{\text {st }}$ Ambar Winarti \\ Nursing Department \\ STIK Muhammadiyah Klaten \\ Jl. Ir Soekarno Km 1 Buntalan 57419 \\ Klaten, Indonesia
maambar37@gmail.com \\ Klaten, Indonesia
Mamaambar37@gmail.com
}

Abstract. The religious tourism is one of the main sectors in Kudus City. There are three interesting attractions in the region: Nature tourism, culture tourism, and the religious tourism. The Mosque Colo is one of the icons in Kudus that has been designated as a tourist destination in Central Java. The positive impact will be felt the community as a environmental impact arising from increased tourism visits is the ability of foreign languages learning for the younger generation, tourism aims specially to visit the religious places. The readiness of the surrounding community in mastering foreign languages is one thing that must be developed in addition to the physical development of supporting facilities and infrastructure. That is an interesting to study is how the efforts of the government and the Mosque Colo communities to prepare themselves in terms of international languages to support the development of the tourism sector in the region. What is the foreign language learning methods? This research uses a qualitative research method focusing on foreign language learning places, economic development. The results of this study are foreign language learning models and the benefit from the economic sector to the communities in the Mosque Colo areas.

Keywords- The historical site, foreign language learning, Economic Development

\section{INTRODUCTION}

In the north of Kudus around $18 \mathrm{~km}$, there is a village called Colo, exactly in the Gawe Subdistrict, Kudus Regency, Central Java. The small village became famous because there buried a guardian who entered the ranks of Wali Songo, with the title Sunan Muria. Her first name is Raden Umar Said.

He got the title Sunan Muria because the place where he preached to spread Islam was located at the Mount Muria of area Even in further developments, he built his pesantren and mosque on the top of the mountain, just behind the mosque he built himself, the mosque which was then known as the mosque colo which was inaugurated as a Regent of KDH Level II Kudus in 1978.

Bangunan bersejarah yang dikategorikan sebagai bangunan cagar budaya juga digunakan sebagai upaya pemerintah dalam melindungi dan melestarikan kekhasan sejarah kota (Dewi, 2016:590).

The building which is categorized as a cultural heritage building is also used as a government effort to protect and preserve the historical characteristics of the Cultural destination is the stretching of the economic sector: The Javanese cultural preservation was inaugurated by the

\author{
$3^{\text {rd }}$ Syahbana Daulay \\ Nursing Department \\ STIK Muhammadiyah Klaten \\ Jl. Ir Soekarno Km 1 Buntalan 57419 \\ Klaten, Indonesia
}

heritage is important because there are many historical relics that have noble historical value and as a source of knowledge. Preservation of cultural heritage is one type of approach in urban planning or spatial planning that aims to maintain, protect, preserve, and utilize cultural heritage buildings for development purposes.

The mosque became one of the importance of Islamic history, a symbol of the propaganda of the saints. One of the historical sites from Sunan Muria is the mosque which is located on the top of the slope of Mount Muria with an altitude of 1,600 meters precisely located in the village of Colo, Kecamatan Dawe, Kudus. To reach the Colo mosque at the top of Mount Muria there are two paths. The first path is by going up approximately 700 stairs on the slope with a height of approximately $1 \mathrm{~km}$ while enjoying the natural surroundings, or the second path by riding a motorcycle taxi to try the adrenaline of pilgrims or visitors due to the winding road and up and down with a steep incline very sharp.

Mosque Colo tourist destinations are only part of the building in the Kudus area because of its unique location on the top of the mountain.

"Cagar budaya merupakan salah satu peninggalan yang dimiliki oleh sebuah komunitas masyarakat. Cagar budaya tidak hanya menceritakan peradaban suatu masyarakat dalam suatu wilayah, tetapi juga perwujudan peradaban umat manusia" (Wibowo, 2014:58).

Cultural heritage is a very important thing to preserve because it has high artistic value and historical value. To preserve the cultural preservation, the protection of the cultural preservation which consists of saving, safeguarding, maintaining and restoring zoning, so as to keep preserving the cultural heritage, the community together with government institutions must cooperate with each other in realizing the preservation of nature reserves in order to maintain their artistic value and historical value (Rosyadi, et al., 2014: 832).

(Wirastari, et al., 2012:63). "Upaya pelestarian yang dilakukan haruslah berdampak pada meningkatnya kesadaran masyarakat, terutama tentang pentingnya keberadaan bangunan-bangunan cagar budaya sehingga masyarakat dapat berperan serta dan mengawasi upaya pelestarian bangunan cagar budaya"

"Upaya pelestarian cagar budaya tidak hanya mempertahankan warisan budaya tetapi juga bagaimana mengembangkan dan memanfaatkan untuk kepentingan hidup sekarang" (Prihantoro dan Yustiadhi, 215:37-38; Ekarini, 2015:29). 
Nowadays the people or and teenagers and the parents tend to prefer visiting modern places, this results in a decrease in public concern for cultural heritage that should be preserved. Therefore, parents and the community working together with the government must try to introduce culture to the youth. Through this cultural introduction, it is hoped that children and young people can be prouder and know the historical value of the culture.

By utilizing technological sophistication, the cultural introduction can be done easily. By establishing places for foreign language courses so that teenagers are more prepared to accept the arrival of foreign tourists, or to move the local cultural sector such as staple foods or local products that can be appointed to drive the economic sector of society. Construction of facilities and infrastructure for easier access such as lodging and culinary specialties.

The results of this study are expected to provide cultural knowledge and learning to the entire community in general and to the younger generation in particular. The importance of information about the existing culture and the sense of ownership so that they will preserve and popularize the culture of Kudus

Kudus culture is important to introduction because at this time the young generation which is an asset of Indonesia's future is less concerned with the culture of the region, therefore the young generation needs to be introduced to its regional culture in order to preserve the existing values and history in the power

\section{METHOD}

The research method used is qualitative, with a multidisciplinary approach, a combination of historical approach and field research or ex post facto, the comparative correlational or causal method. The Qualitative research to chosen for at least two reasons, the first a stability of the researcher the second this research is a nature of it's "(Strauss dan Corbin, 2007:5)." In accordance with various kinds of qualitative data sources that can be used, namely: (1) written sources; (2) oral sources; (3) artifacts; (4) historical heritage; and (5) recording, then to collect written data a library research method is needed. For the collection of oral data contained in oral sources, observation methods are needed and are supported by interviews, while the data in the form of artifacts, historical relics, and records must be observed as carefully as possible (R.M. Soedarsono, 2001: 128).

The basic reason for choosing Kudus as an object is because Kudus is an area or region that has very high religious tourism potential, there are historical buildings and beautiful natural scenery, so there are many interesting locations to be used as research objects.

\section{RESULTS AND DISCUSSION}

Kudus is the city of Wali "Songo", has a long history that is part of the center of Islamic culture. There are many cultural heritages that need to be preserved in the Holy City, such as the Menara Menara Kudus, the Tomb of Sunan Muria, the Kretek Museum and Mount Muria where there is a mosque building known as the Mosque Colo. The cultural heritage is a symbol of culture and economy in the
Holy City. With all the potential possessed by the Holy tour, this place is being developed. Potentials explored include religion, culture, nature, art, culinary, handicraft and others.

The Mosque Colo is included in the Kudus power reserve based on Kudus Regency Regulation No. 11 of 2018 concerning the Kudus Regency Long-Term Development Plan 2020-2025. Pilgrims can enjoy the natural panorama of the cool air while going through the coffee garden to get to the location of the colo mosque located in Colo Village, Dawe District, Kudus Regency, Central Java Province.

To get to the mosque and the tomb of Sunan Muria which is located on the summit of Mount Muria with a height of about 1,600 meters, there are two paths that can be taken the first must walk through the footpaths around 700 's, then the second is available motorcycle taxi with Rp. 10,000 fare one way, by passing a steep rat road with sharp and dangerous turns. Therefore, no other vehicles can pass through it except motorcycle taxis.

The Kudus government has designated the colo area as a tourism area, several villas have been established which can be rented by pilgrims. There are a number of English Language courses but most high school students will take the national exams: Training Institute and Ninda Course courses, EECC Holy English Education Institution, Lia English Language Course is one of the efforts of community care to contribute to preserving cultural heritage by providing a special place for teens and children. young people who care and are ready to welcome the arrival of foreign tourists.

\section{CONCLUSION}

In the digital era, the younger generation tends to prefer modern lifestyles, such as visiting places that are considered modern, rather than visiting tourist attractions that are historical. From this the introduction to culture needs to be done because culture has artistic and historical values that can provide cultural learning to the younger generation. One of the interesting cultural sites of the Kudus to be discussed is the Mosque Colo, because the Mosque Mosque Colo is not only functioning as a unique religious tourist destination but is also a center of economic and cultural activity in the Kudus.

In this study there are things that become obstacles found when $\neg$ being in the location, which often fails to conduct interviews in public places or places that are crowded with human activities, will cause unexpected things, for example there are some sword who are not biased in Indonesian, also young people who take the course only pursue school exam examinations, rarely who deliberately actively take courses for the purpose of welcoming foreign tourists who come to the Kudud area, especially the mosque Colo. This obviously greatly impedes the research process, because it must repeatedly go to places where the course which certainly spent more time and energy. 


\section{REFERENCES}

[1] Antonius, Mikahel, 2013, Studi Tentang Pelestarian Cagar Budaya Masyarakat Dayak Bulusu Di Desa Terindak Kecamatan Sekatak Kabupaten Bulungan, Jurnal Ilmu Pemerintahan, Vol. 1, No. 3.

[2] Butar-Butar, Martina, 2015, Pelestarian Benda Cagar Budaya di Objek Wisata Museum Sang Nila Utama Provinsi Riau, Jurnal Jom FISIP, Vol 2, No.1

[3] Dewi, Faridha Larashati, 2016, Upaya Pelestarian Bangunan Cagar Budaya Perpustakaan Bank Indonesia Surabaya, Jurnal Antrounair, Vol.5, No. 3, pp: 58.

[4] Ekarini, Fr. Dian, 2015, Perizinan dalam Pelestarian Cagar Budaya, Jurnal Konservasi Cagar Budaya Borobudur, Vol. 9, No. 1, pp. 2948

[5] Everett, John. G, Halkali, Hasan, Schlaff, Thomas. G, 1998, Time lapse video aplication for construction project management, Journal of Construction Engineering and Management, 124: 204 - 209

[6] Haryadi, Dwi, 2011, Upaya Perlindungan Benda Cagar Budaya Lawang Sewu Semarang, Jurnal Progresif, Vol. 2, No. 1

[7] Huda, Ahmad, 2015, Pengelolaan Fasilitas Objek Wisata Cagar Budaya Makam Raja Kecik Di Desa Buantan Besar Kabupaten Siak, Jurnal FISIP, No. 2

[8] Krisnawati, Lilik, Suprihardjo, Rima Dewi, 2014, Arahan Pengembangan Kawasan Cagar Budaya Singosari Malang sebagai Heritage Tourism, Jurnal Teknik Pomits, Vol. 3, No. 2.

[9] Kusuma, Arifin Fafan, Darwanto, 2015, Nilai-Nilai Modal Sosial Yang Terkandung Dalam Perkembangan Pariwisata (Studi Kota Surakarta), Jurnal Bisnis dan Ekonomi, Vol. 22, No. 1, pp. 65 $-84$.

[10] Laksana, Praditya Budi, Riyanto, Said, Abdullah, 2015, Strategi Pemasaran Pariwisata Kota Surakarta Melalui City Branding (Studi Pada Dinas Pariwisata \& Kebudayaan Kota Surakarta), Jurnal Administrasi Publik, Vol. 3, No. 1, pp. 73-79

[11] Leushuis, Emile, 2014, Panduan Jelajah Kota-Kota Pusaka di Indonesia, Ombak: Yogyakarta.

[12] Marsono, Prihantoro Fahmi,irawan Popi,S.K Yulita,2018, Dampak Pariwisata religi Kawasan Masjid Sunan Kudus Terhadap Ekonomi Lingkungan Sosial,Sosial Budaya,Gadjah Mada University press.

[13] Nugroho, Setyo Adi, 2015, Pengembangan Alat Bantu Time-Lapse Photography Berbasis Open Source Hardware, Jurnal Ilmiah Komputer Grafis, Vol. 8, No. 1

[14] Panggabean, Sriayu Aretha, 2014, Perubahan dan Fungsi Struktur Bangunan Cagar Budaya Ditinjau dari Perspektif Undang-Undang Cagar Budaya, Jurnal Pandecta, Vol. 9, No. 2

[15] Prihantoro, Fahmi, Yuristiadhi, Ghifari, 2015, Pelestarian Kampung Kauman Yogyakarta Sebagai Kawasan Cagar Budaya Dan Pemanfaatannya 